\title{
Long-Term Efficacy and Safety of Two Doses of Growth Hormone in Short Japanese Children Born Small for Gestational Age
}

\author{
Toshiaki Tanaka $^{a}$ Susumu Yokoya ${ }^{b}$ Yoshiki Seino $^{c}$ Hajime Togari ${ }^{d}$ \\ Jun Mishina ${ }^{e}$ Anne-Marie Kappelgaard ${ }^{g}$ Kenji Fujieda $^{\dagger, f}$

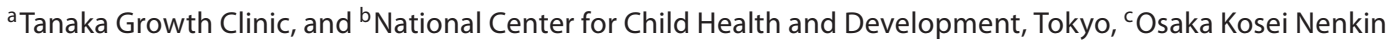 \\ Hospital, Osaka, dNagoya City University, Nagoya, ${ }^{e}$ Nakanoshima Clinic, Tokyo, and ${ }^{\mathrm{f}}$ Asahikawa Medical College, \\ Asahikawa, Japan; ${ }^{9}$ Novo Nordisk A/S, Søborg, Denmark
}

\section{Key Words}

Growth hormone $\cdot$ Small for gestational age $\cdot$ Children . Japanese

\begin{abstract}
Background/Aims: To investigate the long-term efficacy and safety of two doses (33 and $67 \mu \mathrm{g} / \mathrm{kg} / \mathrm{day}$ ) of growth hormone (GH) in short Japanese children born small for gestational age (SGA). Methods: 96 children born SGA (age 3 to $<8$ years) were randomized to $\mathrm{GH}$ at 33 or $67 \mu \mathrm{g} / \mathrm{kg} /$ day for 104 weeks, or to an untreated control (UC) group for 52 weeks. After 52 weeks, the UC group was randomized to GH at a dose of 33 or $67 \mu \mathrm{g} / \mathrm{kg} /$ day for a 156 -week extension study. Initial treatment groups continued unchanged for the extension phase. Efficacy was evaluated by change in height SDS for chronological age from baseline to 208/260 weeks. Results: After 208 weeks, change in height SDS from baseline (least square (LS) means (SE)) was $1.01(0.47)$ and 1.99 (0.67) in the UC 33 and UC $67 \mu \mathrm{g} / \mathrm{kg} /$ day groups, respectively. After 260 weeks, change in height SDS from baseline was $1.22(0.51)$ and $2.01(0.64)$ in the 33 and $67 \mu \mathrm{g} / \mathrm{kg} /$ day groups, respectively. Insulin-like growth factor-1 levels were significantly higher in the groups receiving $67 \mu \mathrm{g} / \mathrm{kg} /$ day but largely remained within normal limits $(-2$ to +2 SDS). Conclu-
\end{abstract}

sion: Long-term continuous GH treatment was well tolerated and effective in improving height SDS. Improvements were dose-dependent and significantly higher at 67 than 33 $\mu \mathrm{g} / \mathrm{kg} / \mathrm{day}$.

Copyright $\odot 2011$ S. Karger AG, Basel

\section{Introduction}

Small for gestational age (SGA) at birth is a relatively common condition, with approximately $5 \%$ of all newborns being below -2 standard deviation scores (SDS) for weight and/or length [1]. While the majority of these children will demonstrate catch-up growth in early life, approximately $10 \%$ of children born SGA will fail to do this by 2 years of age $[2,3]$. This height deficit continues into adulthood, with final adult heights remaining below -2 SDS of mean height $[1,4]$.

There are three main alterations in growth hormone $(\mathrm{GH})$ or insulin-like growth factor-1 (IGF-1) levels that are found in children with short stature born SGA: (i) low levels of GH plus low levels of IGF-1, IGF-2, and insulin-

This paper is dedicated to the late Professor Kenji Fujieda.

\section{KARGER \\ Fax +4161306 1234 E-Mail karger@karger.ch} www.karger.com

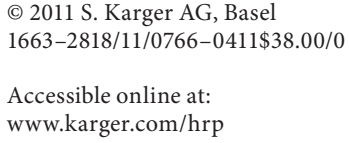

Anne-Marie Kappelgaard

Global Marketing GHT, Novo Nordisk A/S

Vandtårnsvej 108-110, DK-2860 Søborg (Denmark)

Tel. +45 30791650

E-Mail amk@ novonordisk.com 
like growth factor binding protein-3 (IGFBP-3); (ii) normal levels of GH but low levels of IGF-1 and IGFBP-3 suggesting a decreased GH sensitivity, and (iii) decreased IGF-1 sensitivity, as shown by high/normal levels of GH and IGF-1 [5]. High-dose exogenous GH might be able to induce catch-up growth in children with any of these alterations. Indeed, GH therapy improves height velocity $(\mathrm{HV})$ and height SDS at adult height in patients with short stature who are born SGA.

However, the literature is still divided over the best dosing regimen for GH therapy in SGA. Moreover, GH treatment results in reversal of the low IGF-1 levels seen in children with SGA. While this has benefits - low IGF-1 is associated with abnormalities in body composition, aberrant metabolism and increases in cardiovascular risk factors $[6,7]$ - there have been concerns that high levels of IGF-1 may result in an increased risk of malignancies [8]. Current guidance suggests that IGF-1 SDS should be no greater than $2 \mathrm{SD}$ above the mean. Consequently, this study was conducted with the aim of comparing the efficacy and safety of two continuous dosing regimens in promoting catch-up growth and IGF-1 levels over the study period.

This was a 156-week extension study of an initial 104week multicenter, randomized, double-blind, and parallel-group trial (trial registration No. JapicCTI-050132, NCT00184717) investigating the efficacy and safety of two doses of Norditropin ${ }^{\circledR}$ (Novo Nordisk A/S, Denmark) (NN-220) in subjects with short stature born SGA. The total exposure time to NN-220 was 208 and 260 weeks, respectively.

\section{Patients and Methods}

\section{Patients}

The study population was composed of short SGA children. Since the definition of SGA in Japan is newborns being below the 10th percentile of gestational age for both birth weight and birth length, inclusion criteria were as follows: (i) SGA with birth weight and birth length $<10$ th percentile of gestational age; (ii) SGA with birth weight SDS or birth length SDS $\leq-2$ SDS for gestational age; (iii) height SDS for chronological age $\leq-2$ SDS; (iv) chronological age: boys 3 to $<8$ years, girls 3 to $<7$ years; (v) peak GH level of $>10$ $\mathrm{ng} / \mathrm{ml}$ in at least one $\mathrm{GH}$ provocation test conducted within 1 year prior to Visit 1; (vi) HV SDS for chronological age in 1 year prior to Visit 1 (screening visit) of $<0$ SDS, and (vii) prepubertal children (Tanner stage 1 for both boys and girls).

Exclusion criteria included children with known or suspected allergy against $\mathrm{GH}$ or related products (including any component of the trial products); children with serious heart disease, renal disease or hepatic disease; children with diabetes; children with a history or presence of malignancy and/or who had been treated with radiotherapy or chemotherapy. Children who had previous- ly received GH treatment or systemic thyroid hormone, androgen, estrogen, progesterone, anabolic steroid, adrenocortical steroid (except temporary use), analogue of gonadotropin-releasing hormone, and IGF-1 (within 2 years of this trial) were not eligible. Furthermore, children with endocrine diseases, with chromosomal abnormalities or with systemic bone diseases that lead to short stature were also excluded.

The trial was performed in accordance with the Declaration of Helsinki and written informed consent was obtained from the subjects themselves or the subjects' parent/legal guardians.

\section{Study Design}

Patients were initially randomized to one of two GH treatment groups: GH 33 or $67 \mu \mathrm{g} / \mathrm{kg} /$ day for 104 weeks, or to an untreated control (UC) group. After 52 weeks, the UC group was randomized into two treatment groups of GH 33 or $67 \mu \mathrm{g} / \mathrm{kg} /$ day for a further 156 weeks. This was done to give those in the untreated group an opportunity to receive $\mathrm{GH}$. At 104 weeks, those initially randomized to a treatment group in the original trial continued for a further 156 weeks of treatment with the same GH dose.

Results of the initial 104-week treatment phase of the two dose groups compared with the UC group at 52 weeks have been published [9].

The trial product doses ( 5 and $10 \mathrm{mg} / 1.5 \mathrm{ml}$ ) were confirmed indistinguishable from one another and the package box of the trial products was assigned a randomization number and blinded by the person responsible for randomization. Both doses of the trial product were injected using NordiPen ${ }^{\circledR} 5$ (Novo Nordisk A/S) to maintain blinding. Subjects were given a unique subject number written in his/her informed consent and were randomized centrally via minimization [10] and stratified according to age $(<6$ and $\geq 6$ years old).

The primary aims of the trial were to evaluate the long-term efficacy of two doses of $\mathrm{GH}$ ( 33 and $67 \mu \mathrm{g} / \mathrm{kg} / \mathrm{day}$ ) as assessed by change in SDS for chronological age from baseline to 260-/208week treatment in subjects with short stature born SGA, and to evaluate the degree of change in IGF-1 SDS from baseline to $208 / 260$ weeks for each dose. The secondary objectives were to compare the yearly HV SDS for chronological age, change in IGF1 concentrations ( $\Delta$ IGF-1) from baseline to $260 / 208$ weeks, and the safety profile of NN-220 (33 and $67 \mu \mathrm{g} / \mathrm{kg} / \mathrm{day}$ ) as assessed by adverse events, clinical laboratory tests, oral glucose tolerance test, $\mathrm{HbA}_{1 \mathrm{c}}$ (glycosylated hemoglobin $\mathrm{A}_{\mathrm{lc}}$ ) and bone age.

Statistical Analysis

All efficacy analyses were performed on the Full Analysis Set consisting of all randomized patients with efficacy data after treatment start. Change in height SDS from baseline during treatment was analyzed by analysis of variance (ANOVA), with baseline height SDS for chronological age and chronological age as covariates. Secondary endpoints were analyzed using the same statistical model. All tests were two-sided and a significance level of $5 \%$ was used and confidence intervals (CI) were constructed with a confidence limit of $95 \%$.

Sample size of the initial trial was determined from a previous report [11] assuming a dropout rate of $30 \%$ and with $80 \%$ power. Consequently, 19 cases would be required in the control group, 35 cases in the $33 \mu \mathrm{g} / \mathrm{kg} /$ day group and 35 cases in the $67 \mu \mathrm{g} / \mathrm{kg} /$ day group. 


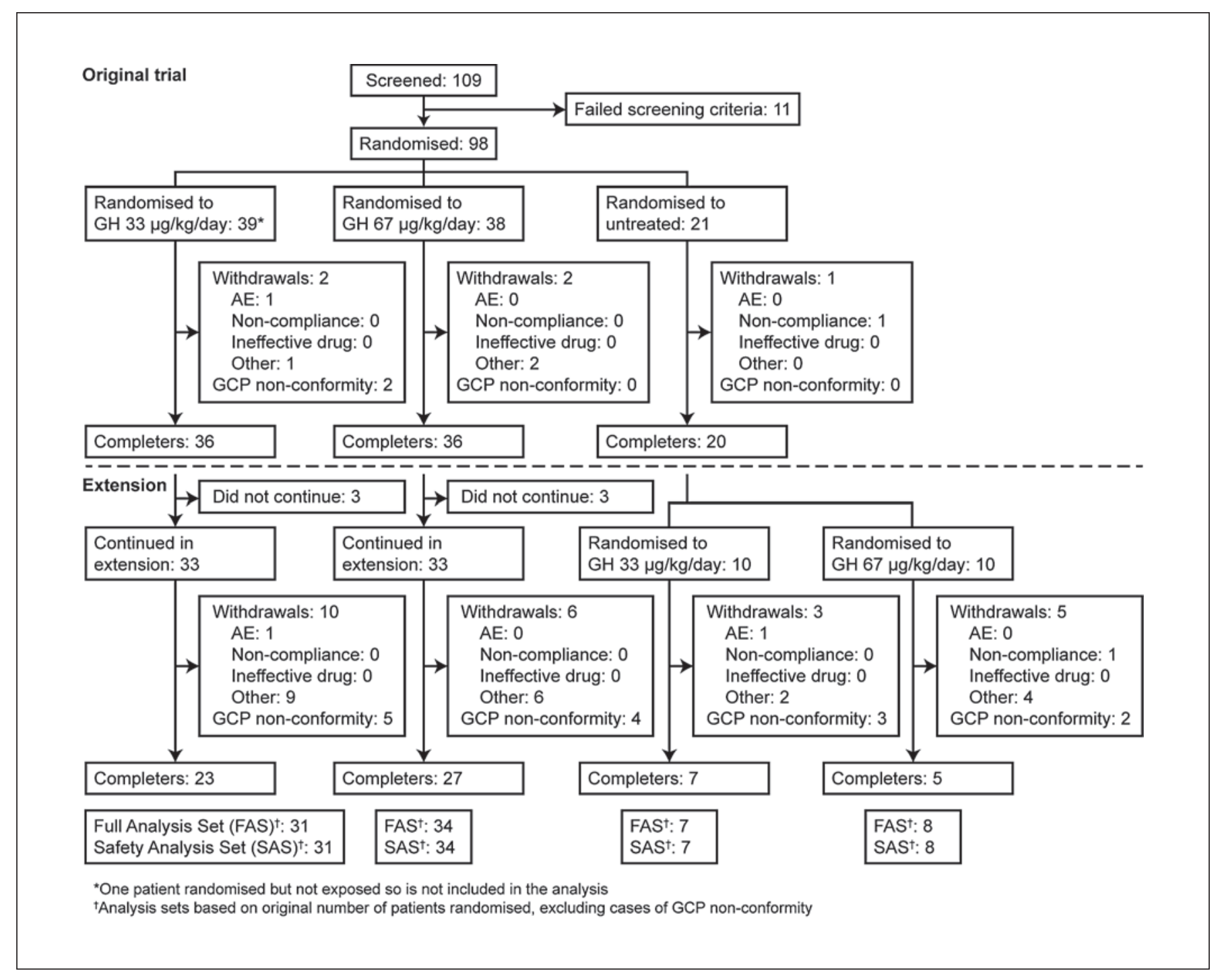

Fig. 1. Patient flow.

\section{Results}

\section{Patient Demographics}

A total of 92 patients completed the initial trial, 20 patients in the 52-week control group, and 36 patients in both 104 -week treatment groups. Of these, 86 patients enrolled in the extension (6 patients in the initial treatment groups did not continue) (fig. 1). Patient characteristics at baseline did not differ between groups (table 1).

\section{Height SDS}

After 208 weeks (4 years), mean (SD) height SDS was $-1.95(0.82)$ in the UC $33 \mu \mathrm{g} / \mathrm{kg} /$ day group and -0.76
(0.75) in the UC $67 \mu \mathrm{g} / \mathrm{kg} /$ day group (p < 0.042) (fig. 2). The change in height SDS from baseline to 208 weeks last observation carried forward (LOCF), LS mean (SE) was $1.01(0.47)$ and $1.99(0.67)$ in the UC 33 and UC $67 \mu \mathrm{g} / \mathrm{kg} /$ day groups, respectively. After 260 weeks (5 years), mean (SD) height SDS was $-1.78(0.78)$ in the $33 \mu \mathrm{g} / \mathrm{kg} /$ day group and $-0.82(0.74)$ in the $67 \mu \mathrm{g} / \mathrm{kg} / \mathrm{day}$ group $(\mathrm{p}<$ 0.001 ) (fig. 2). The change in height SDS from baseline to 260 weeks (LOCF, LS mean (SE)) was $1.22(0.51)$ and 2.01 (0.64) in the 33 and $67 \mu \mathrm{g} / \mathrm{kg} /$ day groups, respectively. 
Table 1. Patient demographics

\begin{tabular}{|c|c|c|c|c|}
\hline & \multicolumn{2}{|l|}{ Original UC group } & \multirow{2}{*}{$\begin{array}{l}33 \mu \mathrm{g} / \mathrm{kg} / \mathrm{day} \\
(\mathrm{n}=31)\end{array}$} & \multirow{2}{*}{$\begin{array}{l}67 \mu \mathrm{g} / \mathrm{kg} / \mathrm{day} \\
(\mathrm{n}=34)\end{array}$} \\
\hline & $33 \mu \mathrm{g} / \mathrm{kg} /$ day $(\mathrm{n}=7)$ & $67 \mu \mathrm{g} / \mathrm{kg} /$ day $(\mathrm{n}=8)$ & & \\
\hline Gender, male/female, n (\%) & $4(57.1) / 3(42.9)$ & $3(37.5) / 5(62.5)$ & $20(64.5) / 11(35.5)$ & $20(58.8) / 14(41.2)$ \\
\hline Chronological age, years & $6.70 \pm 1.22$ & $5.98 \pm 1.51$ & $5.34 \pm 1.46$ & $5.27 \pm 1.15$ \\
\hline Height, $\mathrm{cm}$ & $102.01 \pm 8.05$ & $98.71 \pm 9.36$ & $95.91 \pm 8.38$ & $94.91 \pm 7.29$ \\
\hline Body weight, $\mathrm{kg}$ & $14.33 \pm 3.47$ & $13.88 \pm 2.97$ & $13.37 \pm 2.65$ & $12.79 \pm 1.99$ \\
\hline Gestational age, weeks & $35.57 \pm 5.59$ & $35.13 \pm 3.04$ & $35.87 \pm 3.86$ & $35.94 \pm 3.77$ \\
\hline Length at birth, $\mathrm{cm}$ & $39.16 \pm 9.16$ & $39.43 \pm 5.50$ & $40.09 \pm 4.84$ & $40.09 \pm 5.15$ \\
\hline Body weight at birth, $g$ & $1,736.0 \pm 901.2$ & $1,535.1 \pm 618.0$ & $1,703.3 \pm 606.7$ & $1,653.2 \pm 623.9$ \\
\hline Height SDS for chronological age & $-2.96 \pm 0.67$ & $-2.75 \pm 0.35$ & $-2.95 \pm 0.64$ & $-2.90 \pm 0.67$ \\
\hline HV SDS for chronological age & $0.07 \pm 1.57$ & $-1.36 \pm 0.71$ & $-1.63 \pm 0.97$ & $-2.03 \pm 1.45$ \\
\hline IGF-1, ng/ml & $145.63 \pm 43.50$ & $153.50 \pm 62.99$ & $117.25 \pm 49.13$ & $118.20 \pm 49.10$ \\
\hline
\end{tabular}

All values are mean \pm SD unless stated otherwise. All patient numbers are from the FAS and SAS datasets (see fig. 1).

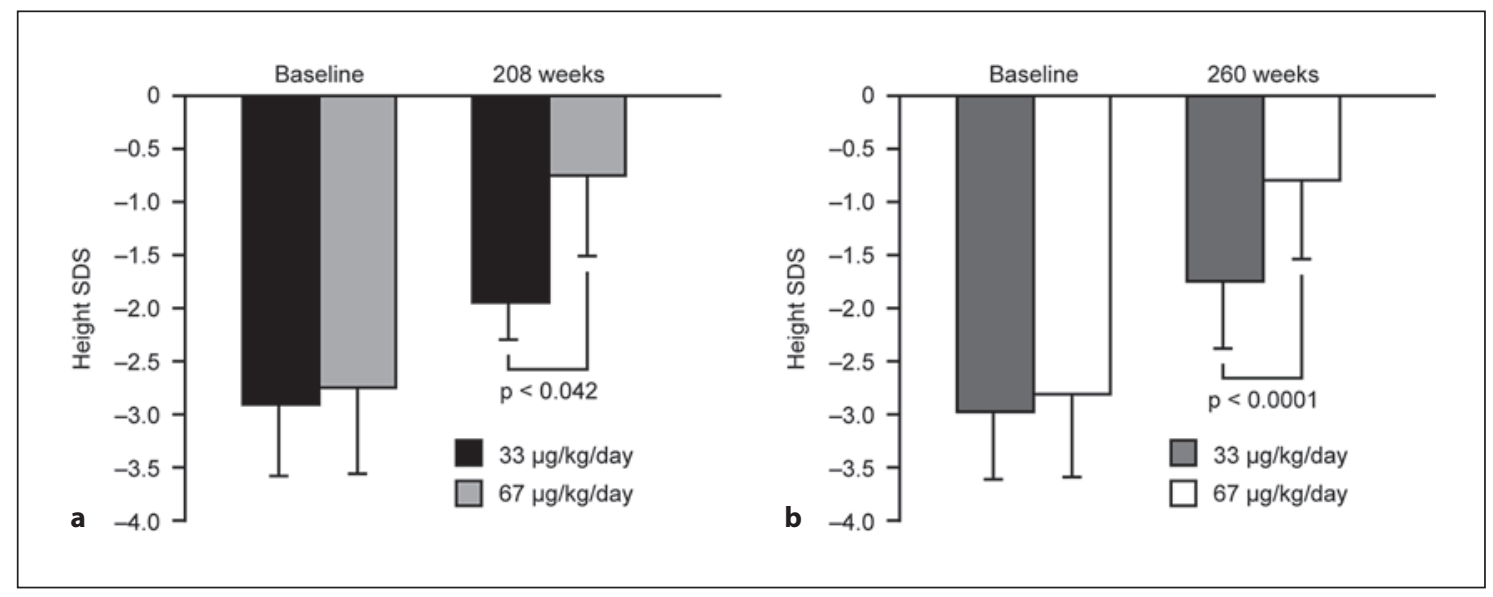

Fig. 2. Analysis of change in height SDS (mean) from baseline to 208 weeks (a, UC group) and 260 weeks (b, initial treatment group).

\section{Height Velocity SDS}

HV SDS increased from baseline, with greater gains in the $67 \mu \mathrm{g} / \mathrm{kg} /$ day groups. The increase in HV SDS was greatest during the first 52 weeks of treatment for all groups (fig. 3). Mean HV SDS for the $67 \mu \mathrm{g} / \mathrm{kg} /$ day group was 1.47 at 4 years falling to 0.80 at 5 years. In the $33 \mu \mathrm{g} /$ $\mathrm{kg} /$ day group, mean HV SDS was 0.40 and 0.46 , respectively during this period. After 208 weeks, the UC 33 and $67 \mu \mathrm{g} / \mathrm{kg} /$ day groups had a mean HV SDS of 0.54 and 2.19 , respectively. The persistence of values above zero suggests that catch-up growth was continuing in all treatment groups.
IGF-1

Significant increases in IGF-1 levels were seen with $\mathrm{GH}$ treatment over 5 years. The change in IGF-1 from baseline to 260 weeks (LOCF, LS mean (SE)) was 342.2 (42.6) and $547.4(41.9) \mathrm{ng} / \mathrm{ml}$ for the 33 and $67 \mu \mathrm{g} / \mathrm{kg} / \mathrm{day}$ groups, respectively (estimated mean difference ( $95 \% \mathrm{CI}$ ) of $205(85,325) \mathrm{ng} / \mathrm{ml}, \mathrm{p}<0.01)$ (table 2$)$.

Analysis of IGF-1 SDS showed a rapid increase in IGF-1 in the first 4 weeks, which was then maintained at a fairly constant level throughout the treatment period. After 260 weeks, the mean IGF-1 SDS was significantly higher in the group receiving $67 \mu \mathrm{g} / \mathrm{kg} / \mathrm{day}(0.77$ and 1.72 for the 33 and $67 \mu \mathrm{g} / \mathrm{kg} /$ day groups, respectively, 
Table 2. IGF-1 levels at baseline and after treatment (mean \pm SD)

\begin{tabular}{lll}
\hline & Baseline & 260 weeks (LOCF) \\
\hline $33 \mu \mathrm{g} / \mathrm{kg} /$ day $(\mathrm{n}=28)$ & $\begin{array}{l}121.58 \pm 49.12 \\
120.07 \pm 49.73\end{array}$ & $\begin{array}{l}465.43 \pm 190.52 \\
665.86 \pm 319.30\end{array}$ \\
\hline $7 \mu \mathrm{g} / \mathrm{kg} /$ day $(\mathrm{n}=29)$ & Baseline & 208 weeks (LOCF) \\
\hline UC 33 $\mu \mathrm{g} / \mathrm{kg} /$ day group $(\mathrm{n}=7)$ & $145.63 \pm 43.50$ & $508.29 \pm 268.55$ \\
UC 67 $\mu \mathrm{g} / \mathrm{kg} /$ day group $(\mathrm{n}=8)$ & $153.50 \pm 62.99$ & $677.88 \pm 342.07$ \\
\hline
\end{tabular}

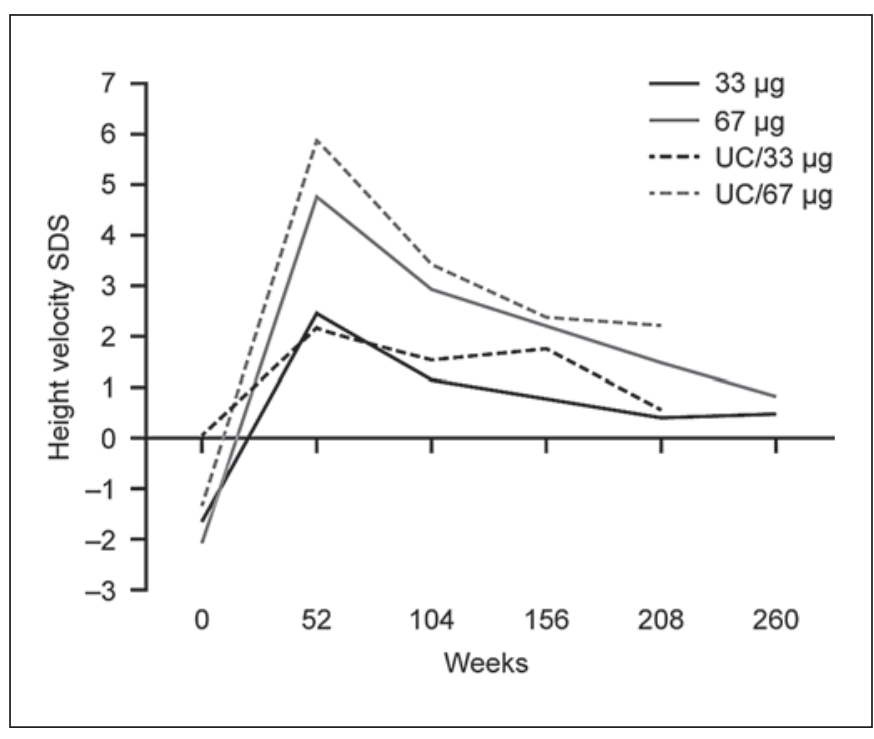

Fig. 3. HV for chronological age during the study period by treatment group.

$\mathrm{p}=0.0114)$. IGF-1 SDS was also consistently higher in the UC $67 \mu \mathrm{g} / \mathrm{kg} /$ day group compared to the UC $33 \mu \mathrm{g} / \mathrm{kg} /$ day group. Although the initial increase in IGF-1 was highest for the UC $67 \mu \mathrm{g} / \mathrm{kg} /$ day group, this was not significantly different from the $67 \mu \mathrm{g} / \mathrm{kg} /$ day group. In the UC $67 \mu \mathrm{g} / \mathrm{kg} /$ day group, between weeks 12 and 39, the IGF-1 SDS exceeded the upper normal range (2 SD above the mean). This was not seen in any of the other groups including the $67 \mu \mathrm{g} / \mathrm{kg} / \mathrm{day}$ group, and may reflect the smaller sample size of the UC $67 \mu \mathrm{g} / \mathrm{kg} /$ day group ( $\mathrm{n}=$ 8 ) compared to the $67 \mu \mathrm{g} / \mathrm{kg} /$ day group $(\mathrm{n}=29)$. Nevertheless, this level of IGF-1 was not consistent in the long term and by week 130 had stabilized at a lower level (fig. 4).

Long-Term Efficacy and Safety of GH in Short Japanese Children Born SGA

\section{IGF-1/IGFBP-3 Molar Ratio}

Baseline IGF-1/IGFBP-3 molar ratios were 0.21 and 0.20 in the 33 and $67 \mu \mathrm{g} / \mathrm{kg} /$ day groups, respectively. By completion of treatment at 260 weeks, IGF-1/IGFBP-3 molar ratios had increased to 0.54 in the $33 \mu \mathrm{g} / \mathrm{kg} /$ day group and 0.71 in the $67 \mu \mathrm{g} / \mathrm{kg} /$ day group. A similar pattern was observed in the UC 33 and UC $67 \mu \mathrm{g} / \mathrm{kg} / \mathrm{day}$ groups. After 208 weeks, increases from 0.22 and 0.21 to 0.57 and 0.67 were observed in the UC 33 and $67 \mu \mathrm{g} / \mathrm{kg} /$ day groups, respectively.

\section{Adverse Events and Glycemic Parameters}

Both doses of GH were well tolerated and few adverse events were considered related to GH treatment. The majority of adverse events were mild-to-moderate infections unrelated to the trial product. Adverse events that were judged probably related to the trial product were predominantly from the musculoskeletal and connective tissue disorders system organ class, and included arthralgia and pain in the extremities. These adverse events were considered a result of accelerated growth and were more frequently reported in the high-dose groups.

After 260 or 208 weeks, profiles of blood glucose in oral glucose tolerance test remained almost unchanged from the baseline while blood insulin levels increased slightly. No subjects were categorized as diabetic type-1 during the treatment period. After 260 weeks of treatment, slight but significant increases from baseline in $\mathrm{HbA}_{1 \mathrm{c}}$ were observed in both the 33 and $67 \mu \mathrm{g} / \mathrm{kg} / \mathrm{day}$ groups, with an estimated mean (95\% CI) of $0.18 \%(0.09$, $0.26)$ and $0.32 \%(0.26,0.38)$, respectively. A significant difference between the two groups was observed, with an estimated mean difference (95\% CI) of $0.14(0.4,0.24)$. $\mathrm{HbA}_{1 \mathrm{c}}$ appeared to slightly increase during the initial 2 years and then remained at the same level until 260 weeks. No subject had an $\mathrm{HbA}_{1 c}$ above the reference range (4.3$5.8 \%)$ during the treatment period. When compared with

Horm Res Paediatr 2011;76:411-418 


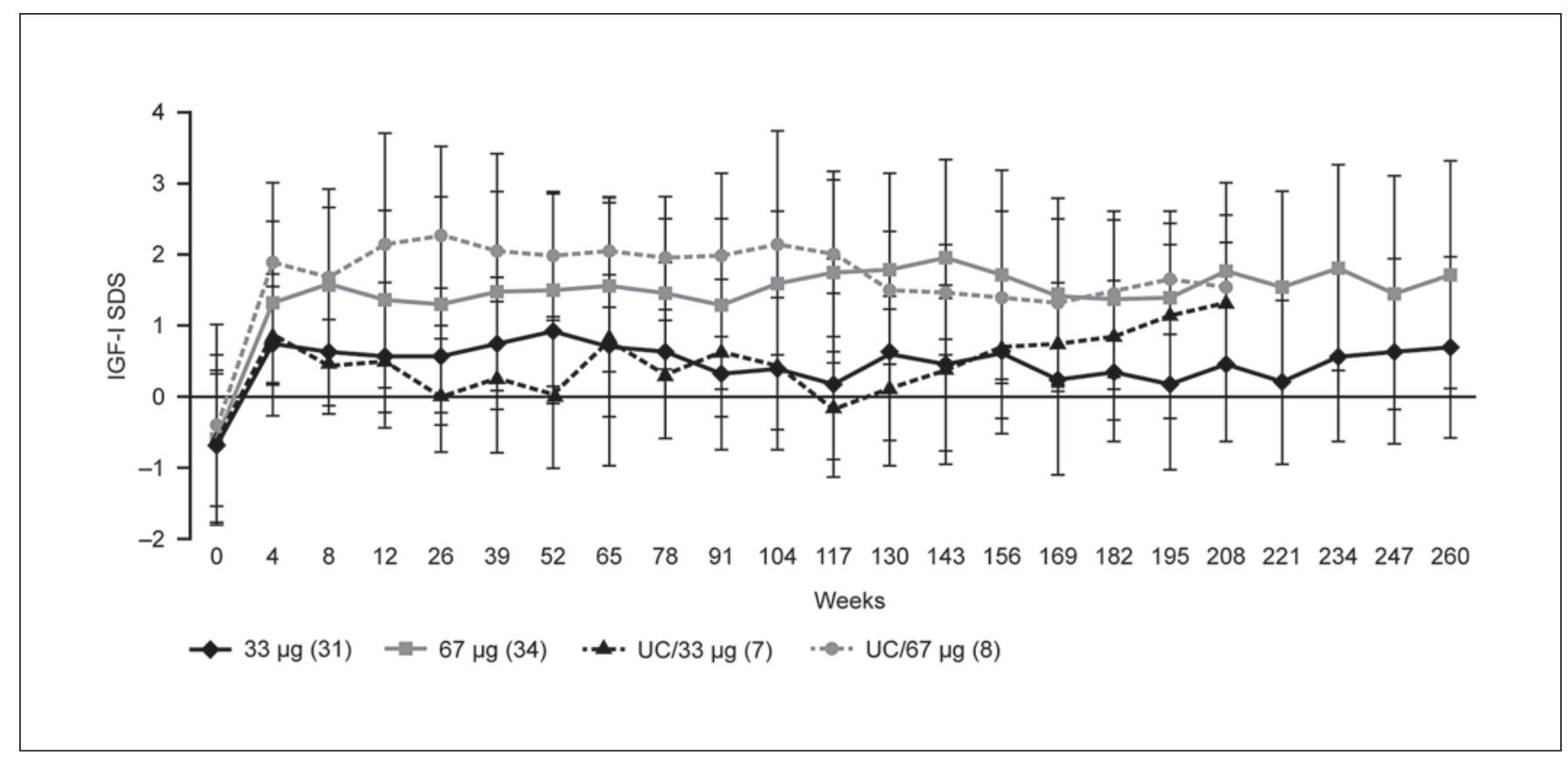

Fig. 4. Change in IGF-1 SDS.

baseline levels, there was a slight but significant increase in $\mathrm{AUC}_{\text {glucose }}$ (at 208 or 260 weeks) in the $33 \mu \mathrm{g} / \mathrm{kg} / \mathrm{day}$ group and a slight but significant increase from baseline in $\mathrm{HbA}_{1 \mathrm{c}}$ was observed for both the 33 and $67 \mu \mathrm{g} / \mathrm{kg} / \mathrm{day}$ groups.

\section{Anti-Human GH Antibodies}

Anti-human GH antibody test positives were observed for a total of 4 subjects in the $33 \mu \mathrm{g} / \mathrm{kg} / \mathrm{day}$ group and 9 subjects in the $67 \mu \mathrm{g} / \mathrm{kg} /$ day group. One subject in the UC $33 \mu \mathrm{g} / \mathrm{kg} /$ day group developed anti-human GH antibodies. The formation of antibodies did not appear to affect height SDS in any of these subjects.

\section{Bone Age}

Mean (SD) increase in bone age during 260 weeks was 5.79 (1.05) years for the $33 \mu \mathrm{g} / \mathrm{kg} / \mathrm{day}$ group and 7.15 (1.05) years for the $67 \mu \mathrm{g} / \mathrm{kg} /$ day group. At 260 weeks, mean bone age/chronological age was approximately 1 in both groups: $1.012(0.13)$ and $1.086(0.098)$ for the two groups, respectively. Mean (SD) increase in bone age during 208 weeks was $6.54(1.26)$ years for the UC $33 \mu \mathrm{g} / \mathrm{kg} /$ day group and 5.60 (1.68) years for the UC $67 \mu \mathrm{g} / \mathrm{kg} /$ day group. At 208 weeks, mean bone age/chronological age was approximately 1 in both groups: $1.048(0.15)$ and $1.015(0.185)$ for the two groups, respectively.

\section{Discussion}

This study demonstrated the efficacy and safety of up to 5 years of two doses of human GH (33 and $67 \mu \mathrm{g} / \mathrm{kg} /$ day) in the treatment of Japanese children with short stature born SGA. Both doses resulted in statistically significant dose-dependent increases in height SDS. The patient demographics of the population at baseline indicated that the children were of shorter stature, had slower $\mathrm{HV}$ and a delay in bone age than the reference population and were therefore considered representative for children born SGA without catch-up growth.

The dose-dependent growth-promoting effect of human GH treatment observed here is consistent with results from European studies involving short children born SGA [11-15].

This study adds to the few publications that have investigated GH treatment over longer periods of time (312 years) for children born SGA [15-17]. These European studies indicate that children born SGA will reach a normal adult height with long-term continuous GH treatment. Results from our study show that this may also be true in Japanese children born SGA as catch-up growth was continuing at 208 weeks of treatment with $67 \mu \mathrm{g} / \mathrm{kg} /$ day. Also consistent with findings from European studies is the observation that $\mathrm{HV}$ was slower in the second year 
of treatment compared to the first year of treatment. In a 2-year study conducted in Germany of 69 prepubertal children born SGA allocated to no treatment or GH treatment at 0.1 or $0.2 \mathrm{IU} / \mathrm{kg} / \mathrm{day}$ ( 33 or $67 \mu \mathrm{g} / \mathrm{kg} /$ day), mean HV SDS after the first year of treatment was -1.2, 2.8 and 5.5 , respectively [18]. Slower HV was seen during the second year with corresponding values of $-0.9,1.6$ and 2.9, respectively. This is also a consistent finding with $\mathrm{GH}$ therapy in other indications, for example Turner syndrome and GH deficiency.

Given the potential association of high circulatory IGF-1 levels and cancer risk, we conducted detailed measurements of the change in IGF-1 throughout the course of the study. In the UC $67 \mu \mathrm{g} / \mathrm{kg} /$ day group, IGF-1 SDS marginally exceeded the recommended guidelines for a period of 27 weeks (the highest IGF-1 SDS being 2.26). However, as the study progressed, the IGF-1 levels in this group stabilized at a lower level, within the normal range. A dose of $33 \mu \mathrm{g} / \mathrm{kg} / \mathrm{day}$ resulted in significantly smaller increases in IGF-1 SDS; however, the improvement in growth, although still significant, was not as great as with the higher $\mathrm{GH}$ dose. It may therefore be prudent to adhere to a lower GH dose, particularly in patients who may be predisposed to certain cancer types. This represents a compromise between achieving sufficient growth and preventing unnecessary exposure to potential risk.

The molar ratio of IGF-1/IGFBP-3 is considered to represent the availability of free IGF-1 which can act to stimulate growth. It has therefore been suggested that monitoring this ratio may aid in evaluating $\mathrm{GH}$ efficacy and safety [19]. By completion of this study, the IGF-1/IGFBP3 ratio had approximately tripled, with the greatest increases observed in the high-dose groups. This is in accordance with the greater gains in height observed in the high-dose groups. Although monitoring IGF-1 levels is an essential safety requirement, our results suggest that also monitoring the IGF-1/IGFBP-3 ratio may provide additional insight. This may be useful in individualizing treatment regimens for efficacy and safety.

Our results also show that gain in height corresponds to nearly normal bone growth. The BA/CA ratio should be about 1 if bone age is appropriate for CA. In this trial, the $\mathrm{BA} / \mathrm{CA}$ ratio was below or close to 1 in most children, therefore not raising any fears regarding accelerated bone maturation.

During the study, 9 children presented with Tanner stage II/III, with the youngest boy to present aged 10.1 years and the youngest girl aged 8.5 years. No significant differences, in terms of pubertal signs, were observed between treatment groups (data not shown) and no subjects with early onset of puberty as an AE were observed. This is in concordance with other studies that have shown $\mathrm{GH}$ treatment does not affect the age of puberty onset in SGA children, and that SGA children do not start puberty at a younger age compared to normal statured children born SGA $[20,21]$.

GH treatment in the study was generally well tolerated in the long term with the majority of adverse events being infections. As the number of adverse events appeared to be higher in the high-dose group compared to the lowdose group, further long-term monitoring for adverse events may still be needed in subjects undergoing longterm continuous GH treatment.

The blood glucose profiles from the oral glucose tolerance test did not appear to change over 4 years of treatment; $\mathrm{HbA}_{1 \mathrm{c}}$ appeared to increase continuously for the first 2 years but then remained at the same level until 208 weeks. This is similar to the tolerability and safety of GH treatment reported in European studies of short stature children born SGA $[11,22]$.

\section{Conclusion}

This study demonstrates that long-term continuous GH treatment was effective in improving height SDS in short prepubertal Japanese children born SGA. After 260 weeks, gain in height SDS was significantly greater with $\mathrm{GH}$ at a dose of $67 \mu \mathrm{g} / \mathrm{kg} /$ day than at $33 \mu \mathrm{g} / \mathrm{kg} /$ day. IGF1 SDS were significantly higher in children receiving 67 $\mu \mathrm{g} / \mathrm{kg} / \mathrm{day}$, but largely remained within the normal range. Overall, GH treatment was safe and well tolerated in this patient population.

References

Horm Res Paediatr 2011;76:411-418
Karlberg J, Albertsson-Wikland K: Growth in full-term small-for-gestational-age infants: from birth to final height. Pediatr Res 1995;38:733-739.

2 Hokken-Koelega AC, De Ridder MA, Lemmen RJ, Den Hartog H, De Muinck KeizerSchrama SM, Drop SL: Children born small for gestational age: do they catch up? Pediatr Res 1995;38:267-271.

3 Itabashi K, Mishna J, Tada H, Sakurai M, Nanri Y, Hirohata Y: Longitudinal follow-up of height up to five years of age in infants born preterm small for gestational age; comparison to full-term small for gestational age infants. Early Hum Dev 2007;83:327-333. 
4 Leger J, Levy-Marchal C, Bloch J, Pinet A, Chevenne D, Porquet D, Collin D, Czernichow P: Reduced final height and indications for insulin resistance in 20-year-olds born small for gestational age: regional cohort study. Br Med J 1997;315:341-347.

5 Albertsson-Wikland K: Growth hormone secretion and growth hormone treatment in children with intrauterine growth retardation. Swedish Paediatric Study Group for Growth Hormone Treatment. Acta Paediatr Scand 1989;349(suppl):35-41.

6 Abdul Shakoor SK, Shalet M: Effects of GH replacement on metabolism and physical performance in GH deficient adults. J Endocrinol Invest 2003;26:911-918.

$>7$ McCallum RW, Petrie JR, Dominiczak AF, Connell JM: Growth hormone deficiency and vascular risk. Clin Endocrinol 2002;57: 11-24.

$>8$ Renehan AG, Zwahlen M, Minder C, O’Dwyer ST, Shalet SM, Egger M: Insulinlike growth factor (IGF)-I, IGF binding protein-3, and cancer risk: systematic review and meta-regression analysis. Lancet 2004; 363:1346-1353.

9 Fujieda K, Tanaka T, Yokoya S, Seino Y, Togari $\mathrm{H}$, Mishina J: Efficacy and safety of 2year growth hormone treatment in Japanese children born small for gestational age (in Japanese). Jap J Pediatr 2010;63:157-168.

10 White SJ, Freedman LS: Allocation of patients to treatment groups in a controlled clinical study. Br J Cancer 1978;37:849-887.

$\checkmark 11$ Boguszewski M, Albertsson-Wikland K, Aronsson S, Gustafsson J, Hagneäs L, Westgren U, Westphal O, Lipsanen-Nyman M, Sipliä I, Gellert P, Müller J, Madsen B: Growth hormone treatment of short children born small-for-gestational-age: the Nordic Multicentre Trial. Acta Paediatr 1998;87:257-263.
12 Chatelain P, Job JC, Blanchard J, Ducret JP, Oliver M, Sagnard L, VanderschuerenLodeweyckx M: Dose-dependent catch-up growth after 2 years of growth hormone treatment in intrauterine growth-retarded children. Belgian and French Pediatric Clinics and Sanofi-Choay (France). J Clin Endocrinol Metab 1994;78:1454-1460.

13 Job JC, Chaussain JL, Job B, Ducret JP, Maes M, Olivier M, Ponte C, Rochiccioli P, Vanderschueren-Lodeweyckx M, Chatelain P: Follow-up of three years of treatment with growth hormone and of one post-treatment year, in children with severe growth retardation of intrauterine onset. Pediatr Res 1996; 39:354-359.

14 De Zegher F, Albertsson-Wikland K, Wilton P, Chatelain P, Jonsson B, Löfström A, Butenandt $\mathrm{O}$, Chaussain JL: Growth hormone treatment of short children born small for gestational age: meta-analysis of four independent, randomized, controlled, multicentre studies. Acta Paediatr 1996;417(suppl): 27-31.

15 Sas T, de Waal W, Mulder P, Houdijk M, Jansen M, Reeser M, Hokken-Koelega A: Growth hormone treatment in children with short stature born small for gestational age: 5 -year results of a randomized, doubleblind, dose-response trial. J Clin Endocrinol Metab 1999;84:3064-3070.

16 Van Pareren Y, Mulder P, Houdijk M, Jansen M, Reeser M, Hokken-Koelega A: Adult height after long-term, continuous GH treatment in short children born small for gestational age: results of a randomized, doubleblind, dose-response GH trial. J Clin Endocrinol Metab 2003;88:3584-3590.
17 Fjellestad-Paulsen A, Simon D, Czernichow P: Short children born small for gestational age and treated with growth hormone for three years have an important catch-down five years after discontinuation of treatment. J Clin Endocrinol Metab 2004;89:12341239.

18 Butenandt O, Lang G: Recombinant human growth hormone in short children born small for gestational age. German Study Group. J Pediatr Endocrinol Metab 1997;10: 275-282.

19 Şiklar Z, Gönül Ö, Berberoğlu M, Bilir P: Combined evaluation of IGF-I and IGFBP-3 as an index of efficacy and safety in growth hormone treated patients. J Clin Res Pediatr Endocrinol 2009; 1:240-243.

20 Leschek EW, Troendle JF, Yanovski JA, Rose SR, Bernstein DB, Cutler GB Jr, Baron J: Effect of growth hormone treatment on testicular function, puberty, and adrenarche in boys with non-growth hormone deficient short stature: a randomized, double-blind, placebo-controlled trial. J Pediatr 2001;138: 406-410.

-21 Boonstra V, Van Pareren Y, Mulder P, Hokken-Koelega A: Puberty in growth hormonetreated children born small for gestational age. J Clin Endocrinol Metab 2003;88:57535758

-22 Arends NJ, Boonstra VH, Mulder PG, Odink RJ, Stokvis-Brantsma WH, Rongen-Westerlaken C, Mulder JC, Delemarre-Van de Waal H, Reeser HM, Jansen M, Waelkens JJ, Hokken-Koelega AC: GH treatment and its effect on bone mineral density, bone maturation and growth in short children born small for gestational age: 3-year results of a randomized, controlled GH trial. Clin Endocrinol (Oxf) 2003;59:779-787. 